Research Article

\title{
SSR MARKERS BASED GENETIC DIVERSITY IN NEPALESE MAIZE LANDRACES
}

\author{
B.K. Joshi ${ }^{1}$, J. Rawat ${ }^{2}$, B. Adhikari ${ }^{1}$ and R. Pokhrel ${ }^{1}$ \\ ${ }^{1}$ National Agriculture Genetic Resources Center, NARC; Khumaltar, Kathmandu, Nepal; \\ ${ }^{2}$ Himalayan College of Agricultural Sciences \& Technology (HICAST), Kalanki \\ Kathmandu, Nepal
}

\begin{abstract}
Knowledge on genetic diversity is necessary for developing new varieties and managing diversity for future use. Five SSR markers were used to develop the DNA finger prints and to assess the diversity of 23 Nepalese maize landraces. Five locus-based DNA finger prints have distinguished majority of the landraces. The average number of alleles was 2 per locus. Umc1333 marker had shown the highest gene diversity, heterozygosity and polymorphism information content (PIC). At landrace level, the highest gene diversity, heterozygosity and PIC values were found in Seto Local and Seti Makai-3. 23 maize landraces formed four clusters and these clusters were related with seed color. Name of landraces also reflected genetic similarity. Genetically similar landraces can be pooled for conservation and creating dynamic diversity rich population. Distantly related landraces (Bhirkaule, Local Seto Makai, Seto Makai-1, Makai Makai-1761) can be used in breeding program. Detection of low genetic diversity might be due to bottleneck effects during the collection of these landraces from farmers. Therefore, collection strategy needs to be revised for capturing maximum diversity.
\end{abstract}

Keywords: Gel analysis, Gene diversity, Maize landrace, SSR marker, DNA finger print

\section{INTRODUCTION}

Maize is the second most important staple food crop in Nepal and is grown under a wide range of agro-climatic and ecological conditions both in hill and plain areas under rainfed complex farming system. The development of high yielding varieties and populations of maize always remains in the target of many countries. Exploration and collection of diversity at genetic levels are the prerequisites for maize breeding. Nepal, being climatically and socioeconomically diverse, possesses a large number of

* Corresponding author: joshibalak@yahoo.com 
different maize landraces adapted from low altitude i.e. 60 AMSL to more than 3000 AMSL (Upadhyay et al., 2003; Joshi et al., 2017; NAGRC, 2019). But they are not given due emphasis on research and education (Joshi et al., 2020), and therefore many of them are at risk of loss from the field. This situation also demands the generation of knowledge on diversity to manage diversity both on-farm and in-situ. Diversity can be measured from the ecosystem to allelic levels using different approaches and markers.

DNA based markers are found very reliable and are playing a significant role in maize breeding. Among the DNA markers, SSR marker is robust, co-dominant, hypervariable, abundant, and uniformly dispersed in plant genomes (Powell et al., 1996; Mohan et al., 1997; Senior et al., 1998). These markers have been extensively used for genetic diversity analysis, parental lines selection, heterosis, and combining ability studies in maize (George et al., 2004; Nguyen et al., 2012). In an analysis of 45 maize inbreeds involving a set of 22 primer pairs derived from maize genome and 20 primer pairs derived from rice genome generated 132 and 181 markers with an average polymorphism information content (PIC) value of 0.83 and 0.38 , respectively (Ranatunga et al., 2009). Clustering pattern of these genotypes based on SSR marker profiles were different from that of morphometric traits (Ranatunga et al., 2009). Among the four important maize varieties in Nepal, 30 SSR markers revealed an average heterozygosity of $45.07 \%$ for varieties, ranging from $35.23 \%$ in Rampur Composite to $54.64 \%$ in Khumal Yellow variety (Gurung et al., 2010). Molecular marker-assisted breeding is contributing significantly to increase the grain yield of maize in USA (Prasanna et al., 2010) but, conventional breeding predominant the maize breeding in Nepal. So far 93 varieties of maize have been released and registered and 520 accessions are being conserved in National Genebank (NAGRC, 2019) but not fully utilized in breeding program (Joshi, 2017). These collections in the Genebank could be valuable resources for advancing the maize breeding for which genetic level information is necessary to generate.

Knowledge of genetic variation and relationships among landraces is important to understand the genetic variability available, to estimate the rare genotypes and alleles, to adopt suitable conservation strategies, to select suitable landraces for developing hybrid as well as high yielding maize populations. Molecular markers greatly facilitate for understanding genetics of a large number of collections conserved in the Genebank. This research was, therefore, conducted to generate DNA profiles of maize landraces, to assess the genetic diversity, to relate maize landraces (accessions) in terms of their genetic information using SSR markers.

\section{MATERIALS AND METHODS}

\section{Maize landraces}

A total of 23 maize landraces from National Genebank, Kathmandu were used in this study. Their passport details are given in Table 1 . These were collected from 11 
districts (Ramechhap, Dadeldhura, Dailekh, Pyuthan, Kaski, Dolpa, Bajura, Lalitpur, Nuwakot, Rasuwa and Bhojpur) within an altitudinal range from 60 to 2530 AMSL. These landraces were collected before 2000 and regenerated latter in Khumaltar.

Table 1. Details of maize landraces used in this study

\begin{tabular}{|c|c|c|c|c|c|c|c|c|}
\hline SN & Landrace & Accession & Collection site & $\begin{array}{l}\text { Latitude } \\
\text { (D) }\end{array}$ & $\begin{array}{l}\text { Longitude } \\
\text { (D) }\end{array}$ & $\begin{array}{l}\text { Altitude } \\
\text { (m) }\end{array}$ & Farmer Name & $\begin{array}{c}\text { Regeneration } \\
\text { year }\end{array}$ \\
\hline 1 & $\begin{array}{l}\text { Sano } \\
\text { Panhelimakai }\end{array}$ & $\mathrm{C} 2605$ & $\begin{array}{l}\text { Thosey 6, Tapu, } \\
\text { Ramechhap }\end{array}$ & 27.596 & 86.264 & 1783 & $\begin{array}{l}\text { Khadga Bahadur } \\
\text { Karki }\end{array}$ & 2012 \\
\hline 2 & Makai-1761 & NPGR-01761 & NK & NK & NK & NK & NK & NK \\
\hline 3 & Mangre & 11035 & $\begin{array}{l}\text { Amargadi-2, } \\
\text { Dadeldhura }\end{array}$ & NK & NK & 1835 & NK & 2008 \\
\hline 4 & Thulochura & 11044 & Radimadi, Dailekh & NK & NK & 800 & NK & 2008 \\
\hline 5 & Seto Local & 11054 & Dhalea, Pyuthan & NK & NK & 800 & NK & 2008 \\
\hline 6 & Makai & 11066 & Rimal-7, Kaski & NK & NK & 1200 & NK & 2008 \\
\hline 7 & Seto Makai-1 & $\mathrm{C} 0691$ & $\begin{array}{l}\text { Likhu-4 Likhu, } \\
\text { Dolpa }\end{array}$ & NK & NK & 2530 & NainaPahadi & 2011 \\
\hline 8 & Ratomakai & NPGR-01706 & Bortan, Bajura & NK & NK & 1720 & NK & 1985 \\
\hline 9 & Pahenlo makai-1 & C5109 & $\begin{array}{l}\text { Dalchoki-3, Goth } \\
\text { Bhanjyang, Lalitpur }\end{array}$ & NK & NK & 1900 & Krishna Sanjel & 2014 \\
\hline 10 & $\begin{array}{l}\text { Mailisathiyama } \\
\text { kai }\end{array}$ & C5051 & $\begin{array}{l}\text { Ratamate-1, } \\
\text { Raigaun, Nuwakot }\end{array}$ & 27.8575 & 85.0625 & 1387 & Shiva Kumari Rai & 2013 \\
\hline 11 & $\begin{array}{l}\text { Amrikane } \\
\text { Makai }\end{array}$ & C4937 & Kaule-6, Nuwakot & 28.0928 & 85.2531 & 1509 & Santa Lama & 2013 \\
\hline 12 & Bhirkaule & C5046 & $\begin{array}{l}\text { Dhaibung- } 6 \\
\text { Dhaibung, Rasuwa }\end{array}$ & 27.9997 & 85.2089 & 1563 & $\begin{array}{l}\text { ChitraKumariNeup } \\
\text { ane }\end{array}$ & 2013 \\
\hline 13 & Sathiyamakai & C5050 & $\begin{array}{l}\text { Ratamate-1, } \\
\text { Raigaun, Nuwakot }\end{array}$ & 27.8575 & 85.0625 & 1387 & Shiva Kumari Rai & 2013 \\
\hline 14 & $\begin{array}{l}\text { Local Seti } \\
\text { Makai }\end{array}$ & C5169 & $\begin{array}{l}\text { Gupteshwor-8, } \\
\text { Bhojpur }\end{array}$ & NK & NK & 60 & Meghraj Shrestha & 2014 \\
\hline 15 & $\begin{array}{l}\text { Dharim Choti } \\
\text { Paheli }\end{array}$ & C5170 & Ranibash-4, Bhojpur & NK & NK & 60 & Mitra Maya Rai & 2014 \\
\hline 16 & Paheli Makai-2 & C5172 & Champe-5, Bhojpur & NK & NK & 60 & $\begin{array}{l}\text { Chhatra Rana } \\
\text { Magar }\end{array}$ & 2014 \\
\hline 17 & Paheli Makai-3 & C5174 & Pancha-2, Bhojpur & NK & NK & NK & Bahadur Rai & 2014 \\
\hline 18 & Sadiya Makai & C5175 & Pyauli-4, Bhojpur & NK & NK & NK & Kumar Karki & 2014 \\
\hline 19 & Purano Local & C5176 & $\begin{array}{l}\text { Gupteshwor-1, } \\
\text { Bhojpur }\end{array}$ & NK & NK & NK & Debi Bhakta Rai & 2014 \\
\hline 20 & Seti Makai-2 & C5177 & Mulpani-8, Bhojpur & NK & NK & NK & KopilaRasayali & 2014 \\
\hline 21 & Paheli Makai-4 & C5178 & Mulpani-7, Bhojpur & NK & NK & NK & TribhubanTamang & 2014 \\
\hline 22 & Paheli Makai-5 & C5179 & Bokhim-5, Bhojpur & NK & NK & NK & SubasKattel & 2014 \\
\hline 23 & Seti Makai-3 & C5180 & Bokhim-7, Bhojpur & NK & NK & NK & Dambar Shrestha & 2014 \\
\hline
\end{tabular}

NK, not known; Some of old collections do not have complete passport information 


\section{DNA extraction, quantification and standard DNA template preparation}

About $2 \mathrm{~g}$ of young and healthy leaf tissue was collected from 20 days old plants. The leaf surface was disinfected with $70 \%$ alcohol. The maize leaves were washed in petri-dish with the help of distilled water and dried. Leaves were cut into fine pieces and transferred to micro-centrifuge tubes. TissueLyser (QIAGEN) was taken in the micro-centrifuge tubes. TissueLyser was run for 10 minutes at 50 oscillations per minute. DNA was extracted following the CTAB method. Briefly, $600 \mu \mathrm{l}$ CTAB $\left(65^{\circ} \mathrm{C}\right.$ pre- heated) and $8 \mu 1$ 2-Mercaptoethanol were added into the micro-centrifuge tube and the tube was inverted several times. Tubes were transferred into a water bath at $65^{\circ} \mathrm{C}$ for $30-45 \mathrm{~min}$. Then the tubes were centrifuged at $15000 \mathrm{rpm}$ for $15 \mathrm{~min}$. The supernatant was pipetted out and transferred into another micro-centrifuge tube and an equal volume of chloroform: alcohol (24:1) was added. After inverting tubes several times, tubes were centrifuged at $15000 \mathrm{rpm}$ for $10 \mathrm{~min}$. The supernatant was transferred to another Eppendorf tube and an equal volume of chloroform: alcohol (24:1) was added. Tubes were inverted several times and centrifuged at $15000 \mathrm{rpm}$ for $10 \mathrm{~min}$. The supernatant was transferred to a fresh tube and $1 / 3^{\text {rd }}$ volume of chilled iso-propanol was added. The tubes were kept into ice and left for $5 \mathrm{~min}$. Tubes were centrifuged at $15000 \mathrm{rpm}$ for $3 \mathrm{~min}$. Supernatant from the tube was discarded, retaining DNA pellet. DNA was washed with $70 \%$ ethanol and separated by centrifuging at $15000 \mathrm{rpm}$ for $2 \mathrm{~min}$. Ethanol was discarded. DNA containing tubes were left for drying. Tris-EDTA buffer (TE) solution $(50 \mu \mathrm{l})$ was added in the tube for the dilution of DNA and was kept in a deep fridge.

The concentration of each DNA sample $(\mathrm{ng} / \mu \mathrm{l})$ was measured by Q5000 UV-Vis Spectrophotometer (Quawell). This nanodrop measures the sample in about 8 seconds with a high degree of accuracy and reproducibility. All measured data were then exported to MS Excel for further analysis. The concentrations of these DNA samples were adjusted to either $50 \mathrm{ng}$ or $100 \mathrm{ng} / \mu \mathrm{l}$ by adding TE buffer. The required TE to be added for making standard DNA template solution (and working DNA solution) was calculated using the formula, C1 (starting concentration) x V1 (starting volume $)=\mathrm{C} 2$ (final concentration) $\mathrm{x}$ V2 (final volume) in MS Excel.

\section{DNA amplification and gel electrophoresis}

Ten SSR primers were selected based on potent to diversity analysis and their linkage with economical traits (e.g. Quality Protein Maize (QPM), drought tolerance, Gray Leaf Spot (GLS) disease resistance). Among them, we found good amplification from only five SSR primers (Table 2) and therefore we used only five for all maize landraces screening. DNA amplification was carried out in $15 \mu$ l reaction volumes consisting of $7.5 \mu 12$ X Green GoTaq ${ }^{\circledR}$ Reaction 
Table 2. Details of SSR primers used in this study

\begin{tabular}{|c|c|c|c|c|c|c|c|}
\hline SN & Primer & Sequence & Chr & $\begin{array}{c}\mathrm{Ta} \\
(\mathrm{Tm}),{ }^{\circ} \mathrm{C}\end{array}$ & $\begin{array}{l}\text { Repeat } \\
\text { motifs }\end{array}$ & Feature & Reference \\
\hline 1 & Bnlg1258 & $\begin{array}{l}\text { F: GGTGAGATCGTCAGGGAAAA } \\
\text { R: GAGAAGGAACCTGATGCTGC }\end{array}$ & 2 & $49(53)$ & AG (24) & $\begin{array}{l}\text { Related to } \\
\text { GLS disease } \\
\text { resistance }\end{array}$ & $\begin{array}{l}\text { Danson et } \\
\text { al., } 2008\end{array}$ \\
\hline 2 & Phi057 & $\begin{array}{l}\text { F: CTCATCAGTGCCGTCGTCCAT } \\
\text { R: CAGTCGCAAGAAACCGTTGCC }\end{array}$ & 7 & $45(56)$ & GCC & $\begin{array}{l}\text { Related to } \\
\text { opaque-2 } \\
\text { and QPM }\end{array}$ & $\begin{array}{l}\text { Jompuk et } \\
\text { al., } 2006\end{array}$ \\
\hline 3 & Bnlg1194 & $\begin{array}{l}\text { F: GCGTTATTAAGGCAAGCTGC } \\
\text { R: ACGTGAAGCAGAGGATCCAT }\end{array}$ & 8 & $58(52)$ & AG (33) & $\begin{array}{l}\text { Related to } \\
\text { QPM }\end{array}$ & $\begin{array}{l}\text { Krishna et } \\
\text { al., } 2012\end{array}$ \\
\hline 4 & Phi031 & $\begin{array}{l}\text { F: GCAACAGGTTACATGAGCTGACGA } \\
\text { R: CCAGCGTGCTGTTCCAGTAGTT }\end{array}$ & 6 & $45(57)$ & GTAC & $\begin{array}{l}\text { Used in } \\
\text { drought } \\
\text { study }\end{array}$ & $\begin{array}{l}\text { Shiri, } \\
2011\end{array}$ \\
\hline 5 & Umc1333 & $\begin{array}{l}\text { F: AGGTAAGCGAGCATCTGAGGGT } \\
\text { R: TCTGGAGACTCTTCTGGGTGAACT }\end{array}$ & 7 & $46(57)$ & (CAG)4 & $\begin{array}{l}\text { Used in } \\
\text { drought } \\
\text { study }\end{array}$ & $\begin{array}{l}\text { Shiri, } \\
2011\end{array}$ \\
\hline
\end{tabular}

QPM, quality protein maize; GLS, gray leaf spot; Chr, Chromosome number. Ta, annealing temperature; $\mathrm{Tm}$, melting temperature

Master Mix, $1.5 \mu 1$ forward and reverse primers each (10 picomole of each primer), $2.5 \mu 1$ nuclease-free water and $2 \mu \mathrm{l}$ DNA (40 ng DNA). The amplification reaction was carried out in a Thermal Cycler (MultiGene OptiMax, Labnet International, Inc.). The basic PCR program was as follows: an initial hot start and denaturing step at $94^{\circ} \mathrm{C}$ for 4 min followed by 30 cycles of a 1 min denaturation at $94^{\circ} \mathrm{C}$, annealing temperature (depending upon primer used) for $1 \mathrm{~min}$ and extension at $72^{\circ} \mathrm{C}$ for $2 \mathrm{~min}$. A final extension step at $72^{\circ} \mathrm{C}$ for $7 \mathrm{~min}$ was performed and stored at $4^{\circ} \mathrm{C}$. Annealing temperature (Ta) was determined $3-5^{\circ} \mathrm{C}$ less than the primer's melting temperature (Tm). Tm of the primer was calculated using Oligo calculator (http://mcb.berkeley.edu/labs/krantz/tools/oligocalc.html).

PCR products were separated on a $2 \%$ agarose gel using $1 \mathrm{x}$ TAE buffer $(2 \mathrm{~g}$ agarose in $100 \mathrm{ml} \mathrm{1x}$ TAE buffer). Ethidium Bromide (EtBr) was used both in the gel and buffer for DNA staining. After cooling of the gel to $60-70^{\circ} \mathrm{C}, \mathrm{EtBr}$ at a concentration of $0.5 \mu \mathrm{g} \mathrm{ml}^{-1}$ was added to the gel. The stock concentration of EtBr was $10 \mathrm{mg} \mathrm{ml}^{-1}$, and therefore, $5 \mu \mathrm{l}$ stock solution $\left(10 \mathrm{mg} \mathrm{ml}^{-1}\right)$ was used for $100 \mathrm{ml}$ gel. Same concentration was also used in buffer solution i.e. $5 \mu \mathrm{l}$ stock solution for $100 \mathrm{ml}$ buffer. $12 \mu \mathrm{l}$ PCR product of each sample was loaded in each well. In the first lane, 2 $\mu \mathrm{l} 100 \mathrm{bp}$ ladder (HiMedia) was loaded. The gels were run for $2 \mathrm{~h}$ at $90 \mathrm{~V}, 50 \mathrm{~mA}$, and $5 \mathrm{~W}$. Upon completion of the run, gels were kept in water for $5 \mathrm{~min}$ and placed in plastic wrap. DNA fragments were visualized under UV light and photographed using a Gel Doc system (UVDI, Major Science). 


\section{Gel processing, scoring and analysis}

Multiple photos were taken from a single gel in the Gel Doc System. The good quality gel was then selected for each set of gels. Gel was analyzed with the method called Photoshop-Excel assisted gel analysis (McDaniel and Pillai, 2002). In this method, gel image was cropped and sharpness, brightness, and contrast were adjusted in Adobe Photoshop. DNA ladder was labeled and distance travel by each band from well position was measured in mm by using Photoshop. We also printed out some gels and measured the fragment size of the ladder as per the company information to crosscheck. Then, the migration distances were measured using a scale. We found Photoshop easier and accurate. In a similar way, migration distances of each band of samples were measured and recorded. Molecular weight and distance of each band of the ladder were entered in MS Excel. DNA ladder standard (DLS) curve was generated from ladder bands' weight and distance. There is a linear relation between LOG (DNA size) and distance (in $\mathrm{mm}$ ). Therefore, molecular weights were transformed to LOG to base 10. Scatter plot along with trend line and equation were drawn in MS Excel between log-transformed fragment weights and migrated distances. Using this equation, fragment sizes of other bands were estimated. This equation gives the size in LOG to the base 10, and therefore, the actual size of the fragment in bp was antilog of that equation value. This estimated value was further double checked to compare with ladder size in the gel. Using a straight line in Photoshop and based on fragment size and distance, the number of alleles was estimated in the first gel. Alleles identified in the first gel were first detected in other gels of the same primer for remaining samples and if new alleles found, its size was then recorded following the above procedure.

Two-way table was prepared using samples as row name and primer as column name. Actual bp (genetic allele size) was recorded either in homozygous or heterozygous state. This table was formatted as per the requirement of software and then analyzed. DNA finger print of each sample with multiple markers was prepared in MS Excel based on fragment sizes and distances. Summary statistics for primers and maize landraces were estimated along with cluster and principal coordinate analyses in GenAlEx6.5 and Power Marker 3.2. Dendrogram was viewed in Tree View.

\section{SSR profiles}

Five primers amplified the DNA of 23 maize landraces. None of the single primers could differentiate all maize landraces. SSR profile of Bnlg1194 marker is shown in Fig 1. 


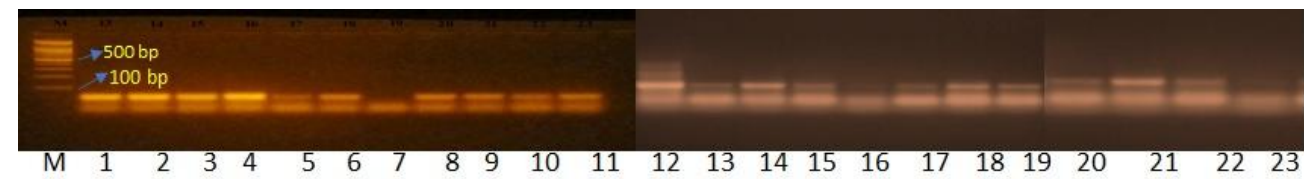

Figure 1. SSR profile of 23 maize landraces with Bnlg1194 SSR marker in agarose gel M, 100 bp marker; Lane number is indicated by the number which corresponds with landraces listed in Table 1

Most of the loci are heterozygotes. Seto Makai-1, Paheli Makai-2 and Seti Makai-3 had homozygote for Bnlg1194 marker. Multilocus DNA fingerprint distinguished the many maize landraces from each other (Fig. 2). Rato Makai and Bhirkaule had larger size alleles compare to Mangre Makai and Seto Makai-1. Rato Makai had heterozygotes for all loci except for Bnlg1258.

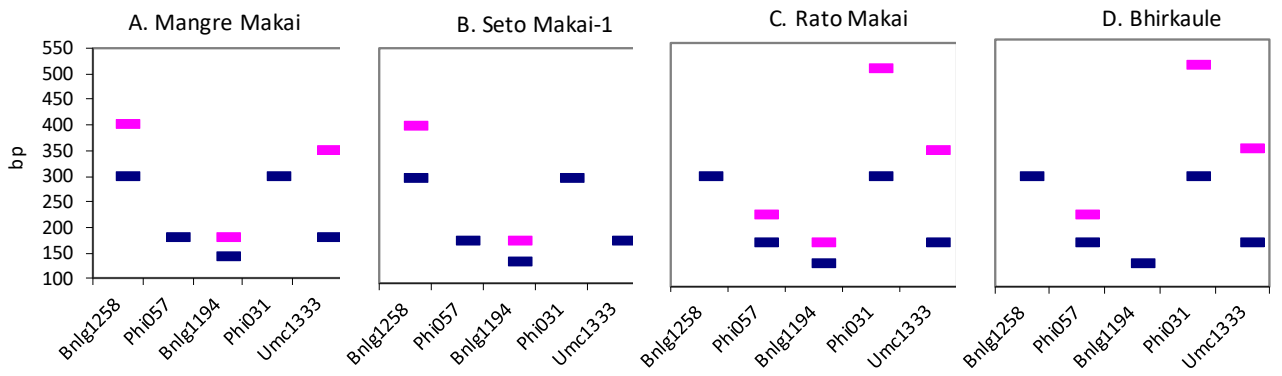

Figure 2. DNA fingerprints of four maize landraces based on five SSR markers

DNA fingerprints are the most reliable testing and identification means. Fingerprint with a single SSR primer might not be always useful and powerful for discriminating genotypes. Therefore, we generated multi locus SSR markers-based fingerprints. Based on these allele size patterns, it will also be useful to select multiple traits related to genotypes. Status of loci e.g. whether heterozygotes or homozygotes can easily be determined and based on which further breeding and conservation works can be planned. DNA fingerprint has been used as a ready reference for identification of maize hybrids and authentication of genetic purity of different seed lots (Singh et al., 2014).

\section{SSR markers diversity}

The size of amplified bands ranged from 140 bp by Bnlg1194 to 500 bp by Phi031 marker (Table 3). All five markers revealed only 2 alleles per locus. The major allele frequency of Bnlg1258 was the highest followed by Phi057. The frequency of $400 \mathrm{bp}$ allele of Bnlg1258 was the lowest (Fig. 3). 


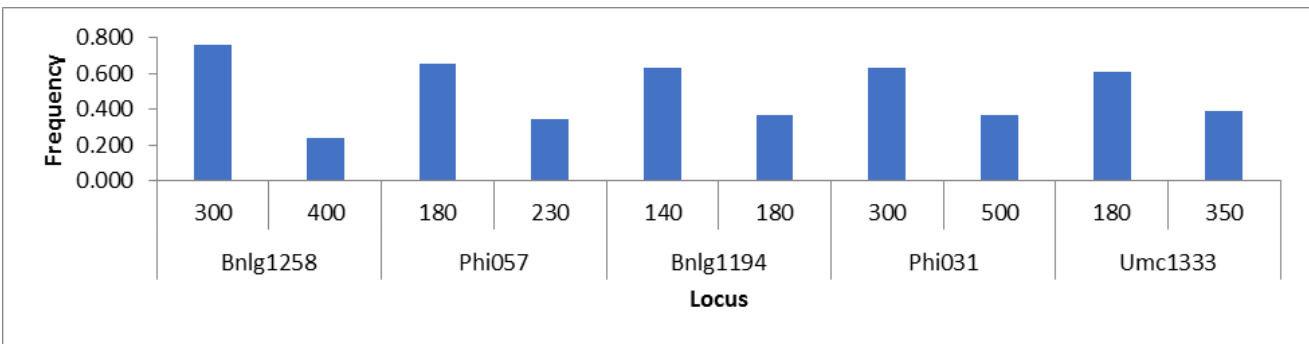

Figure 3. Allele frequency of five SSR markers based on 23 maize landraces

The highest heterozygosity and gene diversity were shown in Umc 1333 whereas Bnlg1258 had shown the lowest heterozygosity as well as the lowest gene diversity. The average Shannon information index (I) and polymorphism information content were 0.637 and 0.345 , respectively. The Shannon index and PIC of Umc1333 were the highest whereas these values of Bnlg1258 were the lowest. All the diversity measures of Umc1333 were the highest and of Bnlg1258 the lowest.

Table 3. SSR markers summary statistics based on 23 maize landraces

\begin{tabular}{lccccccc}
\hline $\begin{array}{c}\text { SSR } \\
\text { Marker }\end{array}$ & $\begin{array}{c}\text { Allele } \\
\text { size, bp }\end{array}$ & $\begin{array}{c}\text { Allele/ } \\
\text { locus, } n\end{array}$ & $\begin{array}{c}\text { Major } \\
\text { Allele } \\
\text { Frequency }\end{array}$ & $\begin{array}{c}\text { Observed } \\
\text { Heterozyg } \\
\text { osity (Ho) }\end{array}$ & $\begin{array}{c}\text { Expected } \\
\text { Heterozygosity } \\
\text { (genediversity) } \\
\text { (He) }\end{array}$ & $\begin{array}{c}\text { Shannon } \\
\text { informati } \\
\text { on index } \\
\text { (I) }\end{array}$ & PIC \\
\hline Bnlg1258 & 300,400 & 2 & 0.761 & 0.478 & 0.364 & 0.550 & 0.298 \\
Phi057 & 180,230 & 2 & 0.652 & 0.696 & 0.454 & 0.646 & 0.351 \\
Bnlg1194 & 140,180 & 2 & 0.630 & 0.739 & 0.466 & 0.659 & 0.357 \\
Phi031 & 300,500 & 2 & 0.630 & 0.739 & 0.466 & 0.659 & 0.357 \\
Umc1333 & 180,350 & 2 & 0.609 & 0.783 & 0.476 & 0.669 & 0.363 \\
Mean & & 2 & 0.657 & 0.687 & 0.445 & 0.637 & 0.345 \\
\hline
\end{tabular}

bp, base pair; PIC, polymorphism information content

DNA finger prints are commonly used to assess the genetic diversity among the studied genotypes. We observed narrow genetic diversity in terms of different genetical statistics e.g. allele per locus, allele frequency, gene diversity, heterozygosity, and PIC. Thee landraces were collected from different districts, agroecology, and altitudes, though, diversity is relatively captured low. This might be because of the small amount of seed samples during collection and/or controlled pollination in small plot and small populations during regeneration in Genebank. In addition, farmers in Nepal generally saved seed themselves and this might be resulted in narrowing the genetic diversity within landraces. This is also supported by observing some homozygous loci, which is not commonly assumed in highly cross- 
pollinated crops like maize. This narrow genetic background with some homozygous loci is expected to contribute to the low grain yield of these maize landraces. In addition, the small number of SSR markers used in this study could not capture total diversity.

\section{Maize landraces diversity}

Six landraces have shown allele sizes ranging from $140 \mathrm{bp}$ to $400 \mathrm{bp}$. Rest of the landraces have allele sizes ranging from 140 to $500 \mathrm{bp}$ (Table 4). The average allele per locus was 1.69. Seto Local and Seti Makai-3 have 2 alleles per locus whereas

Table 4. Summary genetic statistics of maize landraces based on 5 SSR markers

\begin{tabular}{|c|c|c|c|c|c|c|c|}
\hline $\mathrm{SN}$ & Landrace & $\begin{array}{c}\text { Allele size } \\
\text { range, bp }\end{array}$ & $\begin{array}{l}\text { Allele/ } \\
\text { locus, } \mathrm{n}\end{array}$ & $\begin{array}{c}\text { Major Allele } \\
\text { Frequency }\end{array}$ & $\begin{array}{c}\text { Gene } \\
\text { Diversity }\end{array}$ & $\begin{array}{c}\text { Heterozygo } \\
\text { sity }\end{array}$ & PIC \\
\hline 1 & Sano-Paheli & $140-500$ & 1.8 & 0.6 & 0.4 & 0.8 & 0.300 \\
\hline 2 & Makai-1761 & $140-500$ & 1.6 & 0.7 & 0.3 & 0.6 & 0.225 \\
\hline 3 & Mangre & $140-400$ & 1.6 & 0.7 & 0.3 & 0.6 & 0.225 \\
\hline 4 & Thulochura & $140-500$ & 1.4 & 0.8 & 0.2 & 0.4 & 0.150 \\
\hline 5 & Seto-local & $140-400$ & 2 & 0.5 & 0.5 & 1 & 0.375 \\
\hline 6 & Makai & $140-500$ & 1.6 & 0.7 & 0.3 & 0.6 & 0.225 \\
\hline 7 & Seto-Makai-1 & $140-400$ & 1.6 & 0.7 & 0.3 & 0.6 & 0.225 \\
\hline 8 & Rato-Makai & $140-500$ & 1.6 & 0.7 & 0.3 & 0.6 & 0.225 \\
\hline 9 & Pahelo-Makai-1 & $140-500$ & 1.8 & 0.6 & 0.4 & 0.8 & 0.300 \\
\hline 10 & Mailisathyan-Makai & $140-500$ & 1.8 & 0.6 & 0.4 & 0.8 & 0.300 \\
\hline 11 & Amrikane-Makai & $140-500$ & 1.8 & 0.6 & 0.4 & 0.8 & 0.300 \\
\hline 12 & Bhirkaule & $140-500$ & 1.8 & 0.6 & 0.4 & 0.8 & 0.300 \\
\hline 13 & Sathya-Makai & $140-500$ & 1.8 & 0.6 & 0.4 & 0.8 & 0.300 \\
\hline 14 & Local-Seto-Makai & $140-400$ & 1.6 & 0.7 & 0.3 & 0.6 & 0.225 \\
\hline 15 & Dharim-Choti & $140-500$ & 1.8 & 0.6 & 0.4 & 0.8 & 0.300 \\
\hline 16 & Pahelo-Makai-2 & $140-500$ & 1.6 & 0.7 & 0.3 & 0.6 & 0.225 \\
\hline 17 & Pahelo-Makai-3 & $140-500$ & 1.8 & 0.6 & 0.4 & 0.8 & 0.300 \\
\hline 18 & Sadiya-Makai & $140-500$ & 1.6 & 0.7 & 0.3 & 0.6 & 0.225 \\
\hline 19 & Purano-Local & $140-500$ & 1.6 & 0.7 & 0.3 & 0.6 & 0.225 \\
\hline 20 & Seti-Makai-2 & $140-400$ & 1.6 & 0.7 & 0.3 & 0.6 & 0.225 \\
\hline 21 & Paheli-Makai-4 & $140-500$ & 1.6 & 0.7 & 0.3 & 0.6 & 0.225 \\
\hline 22 & Paheli-Makai-5 & $140-500$ & 1.4 & 0.8 & 0.2 & 0.4 & 0.150 \\
\hline \multirow[t]{2}{*}{23} & Seti-Makai-3 & $140-400$ & 2 & 0.5 & 0.5 & 1 & 0.375 \\
\hline & Average & & 1.69 & 0.66 & 0.34 & 0.69 & 0.258 \\
\hline
\end{tabular}

bp, base pair; PIC, polymorphism information content 
Thulochura and Paheli Makai-5 have just 1.4 alleles per locus. Major allele frequency of these two landraces (Thulochura and Paheli Makai-5) was the highest whereas the lowest major allele frequency was found in Seto Local and Seti Makai-3. The average values for gene diversity, heterozygosity, and PIC were $0.34,0.69$, and 0.258 , respectively. The lowest genetic diversity measures (gene diversity, heterozygosity and PIC) were observed in Thulochura and Paheli Makai-5. The highest gene diversity, heterozygosity and PIC values were found in Seto Local and Seti Makai-3.

It is very common to report the diversity of each marker. But diversity over landraces combining all studied markers would be more useful to directly pick up the landraces for various purposes. We have found in Seto Local and Seti Makai-3 more diverse in comparison to other landraces. Some of these landraces have similar values indicating genetic similarity and potential candidates for pooling together for conservation and mixing populations.

There are a number of studies that revealed similar genetic statistics. Gurung et al. (2010) reported $45.07 \%$ average heterozygosity at the variety level, with a maximum heterozygosity of $54.64 \%$ in Arun-4 variety. Phi109188 showed the maximum heterozygosity $(81.03 \%)$. Khumal Yellow showed the highest gene diversity $(0.56)$. The gene diversity at the variety level ranged from 0.51 in Manakamana-2 to 0.56 in Khumal Yellow and Arun-4. Reif et al. (2003)reported the gene diversity of 0.56 in tropical maize population. PIC for 34 SSRs on QPM was found from 0.50 to 0.95 . The highest PIC was of bnlg1401 and the lowest of bnlg1506 (Krishna et al., 2012). A total 19 polymorphic alleles were found in 8 maize genotypes using 9 polymorphic SSR primers with 0.297 PIC and 0.373 gene diversity values (Kumari et al., 2018). The phi064 and phi053 were found as the best marker for identification of genotypes as revealed by PIC values (0.367). A total of 40 alleles (bands) with a mean of 3.33 alleles per locus were detected in 38 maize hybrids using 12 SSR markers (Shiri, 2011). Polymorphism information content (PIC) of the 12 SSR loci ranged from 0.23 (Phi080) to 0.79 (UMC2359), with a mean PIC of 0.53.

\section{Genetic relatedness among maize landraces}

Based on genetic distance, 23 maize landraces made 4 clusters (Fig 4). 


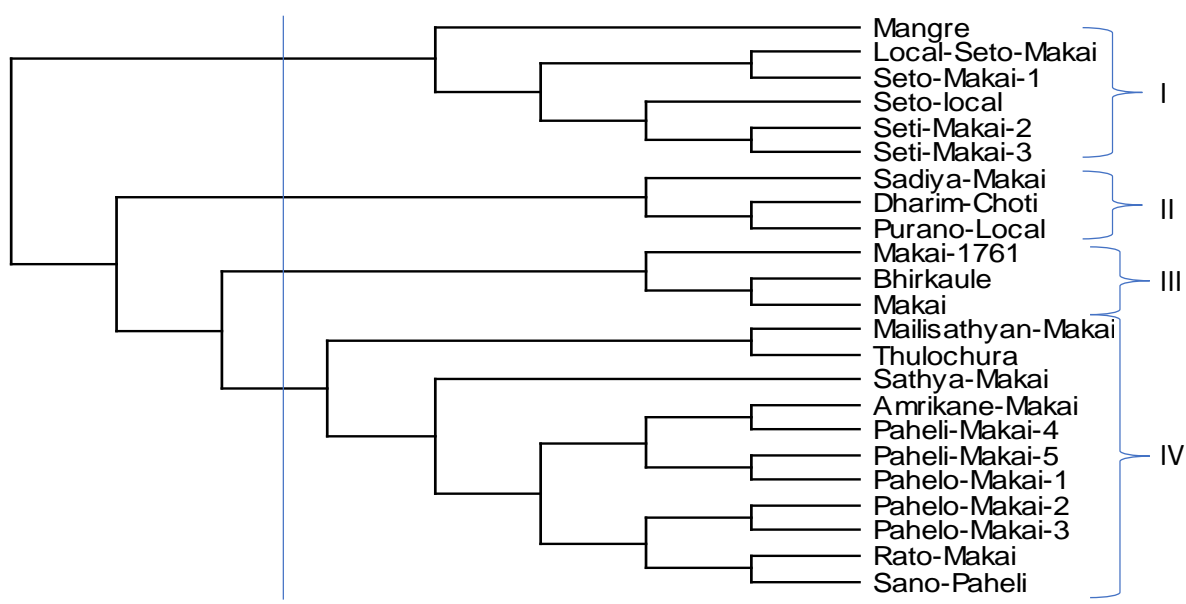

Figure 4. Clustering of 23 maize landraces based on 5 SSR markers using UPGMA method

Mantel test was used to analyze the 'goodness of fit' for the UPGMA dendrogram. Mantel test indicated the clustering of these landraces is reliable with cophenetic correlation value of 0.95. Cluster I consisted of 6 landraces, cluster II and III each consisted of 3 landraces and cluster IV has included 11 landraces. Clusters were related to seed color or local name. For example, landraces with Seto (white seed) name clustered together and name associated with Pahelo formed a separate cluster. Most closely related landraces were between Local Seto Makai and Seto Makai-1, Seti Makai-2 and Seti Makai-3, Sano-Paheli and Rato Makai. Most distantly related landraces were of Bhirkaule with Local Seto Makai and Seto Makai-1, of Makai with Local Seto Makai and Seto Makai-1, and of Makai-1761 with, Local Seto Makai and Seto Makai-1.

Clustering of landraces is practically more useful to see the genetic relatedness and to select landraces in breeding and conservation programs. Two principal coordinates are sufficiently separated these 23 maize accessions into four groups as did by cluster analysis. We found that name of landraces also reflected some genetic similarity. In Nepal, farmers usually give names to landraces based on seed color and size. White seed colored landraces are grouped together and similarly, yellow seed colored landraces made a separate cluster. Many landraces in this study have shown very similar at genetic levels indicating the potentiality of pooling together for reducing the number of accessions to be managed in the Genebank. On the other hand, genetically dissimilar landraces can be selected for developing a new population as well as a composite or mixture population. It is common to observe the cluster in SSR markers-based study. By using UPGMA cluster analysis, the eight genotypes were grouped under 3 clusters (Kumari et al., 2018) based on the genetic distances ranging from 0.21 to 0.64 . 
Clustering of these landraces is also equally explained by two principal coordinates. Four groups were formed in scatter plot of two principal coordinates (Fig 5). First and second PCs accounted for 52 and $29 \%$ of the total variance. Collection districts of each landrace are indexed on top of the Fig 5.

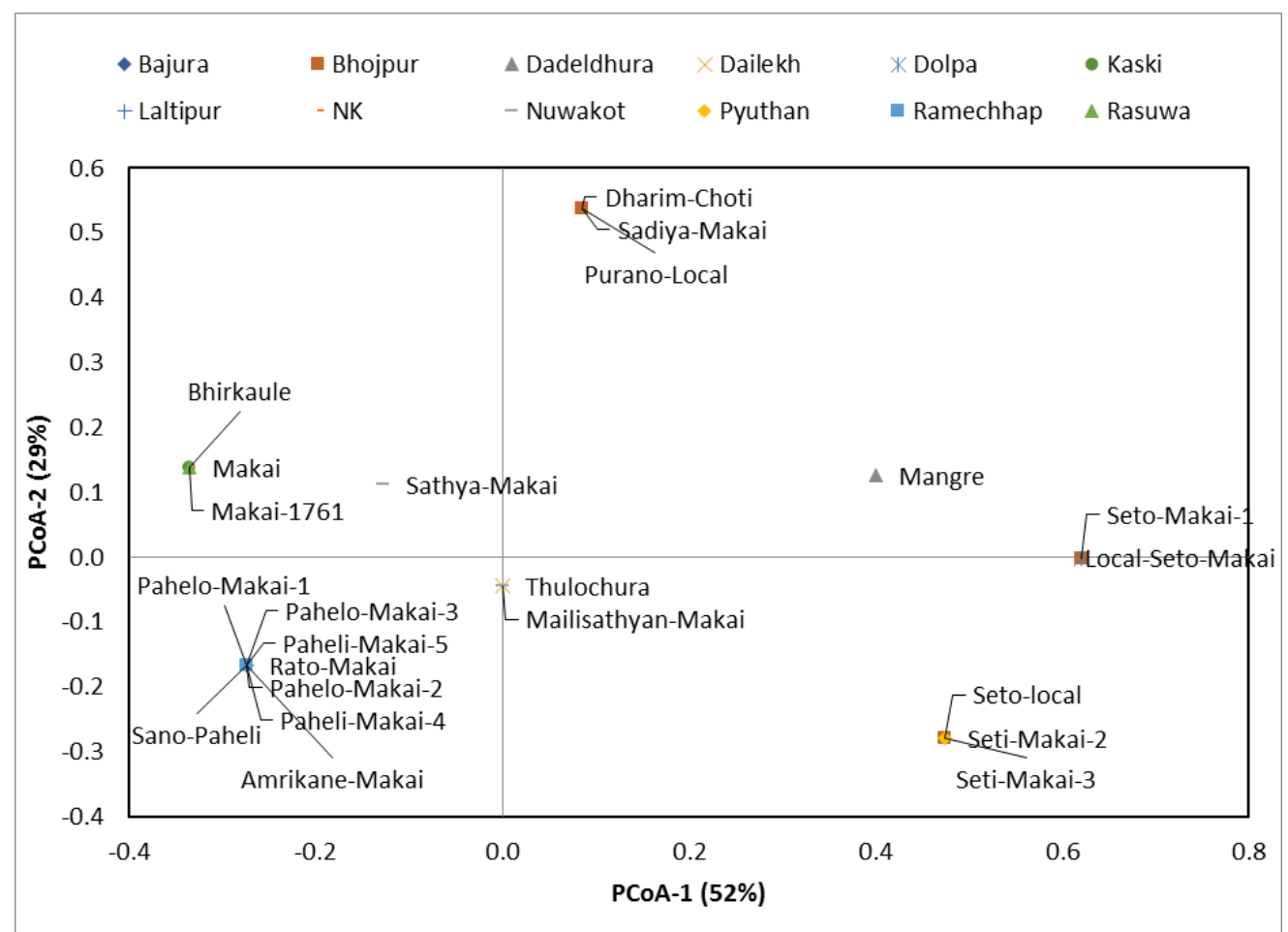

Figure 5. Principal coordinate analysis of 23 maize landraces using five SSR markers The legend on the top indicates the collection districts. NK, not known

The geographical association was not found among the landraces collected from Nuwakot and Bhojpur. Only a single landrace was collected from the rest of the districts. Majority of these landraces were found similar and therefore, plotted in the same point e.g. Sadiya Makai, Dharim Choti and Purano Local.

We have also given due priority to those markers that have linked with some economical traits. Such markers are very useful for identifying desired genotypes. The ultimate action of DNA markers is to accelerate the breeding through adopting marker assisted selection (MAS). MAS in maize is being used increasingly. SSR markers, namely UMC1862, UMC1719, UMC1447, UMC2359, and UMC1432, have significantly contributed to the differentiation of the drought-tolerant and susceptible genotypes (Shiri, 2011). The putative QTLs for GLS have been reported in association with two SSR markers (bnlg1258 and umc2019) in chromosome 2 and for common rust, the associated SSR markers were phi054, umc1319, and bnlg1451 
in chromosome 10 (Danson et al., 2008). SSR marker has become useful on selecting opaque 2 gene in maize genotypes, therefore, there is no need of routine biochemical analysis for high lysine and tryptophan levels at each backcross populations or any other segregating lines (Danson et al., 2006). Phi057 was considered more feasible than phi112 as a marker assisted selection (MAS) for opaque-2 and to identify QPM line in the short period of time (Jompuk et al., 2006). Several thousand SSR markers of maize genomes are available in the public domain (Maize GDB; http://www.maizegdb.org). In addition to diversity related markers, MAS can be effectively applied in maize breeding using economically important traits linked markers that are available on the Maize GDB website. This online information as well as diversity reported here can greatly help to manage and utilize Nepalese maize landraces.

\section{CONCLUSION}

Five SSR markers amplified the DNA of all 23 maize landraces with almost similar fragment sizes. Multiple loci-based DNA fingerprints were more discriminating power. Genetic diversity in this study was low even though landraces were collected from different districts and altitudes. Genetically similar landraces can be considered as duplicates and should be merged to maintain the long run in the genebank. Maize is a cross-pollinated crop; however, all the loci were not heterozygotes. Low genetic diversity may be due to the low number of SSR markers as well as bottleneck effects during collection from farmers. Additional markers need to screen for further validating the similarity among the landraces along with redefining the collection strategy and method.

\section{ACKNOWLEDGMENTS}

We thank National Genebank for providing seeds of maize landraces. Nepal Agricultural Research Council supported financially for this study.

\section{REFERENCES}

Danson, J., Lagat, M., Kimani, M. and Kuria, A. (2008). Quantitative trait loci (QTLs) for resistance to gray leaf spot and common rust diseases of maize. African Journal of Biotechnology, 7: 3247-3254.

Danson, J.W., Mbogori, M., Kimani, M., Lagat, M., Kuria, A. and Diallo, A. (2006). Marker assisted introgression of opaque2 gene into herbicide resistant elite maize inbred lines. African Journal of Biotechnology, 5: 2417-2422.

George, M.L.C., Regalado, E., Li, W., Cao, M., Dahlan, M., Pabendon, M., Warburton, M.L., Xianchun, X. and Hoisington, D. (2004). Molecular characterization of Asian maize inbred lines by multiple laboratories. Theoretical and Applied Genetics, 109: 80-91.

Gurung, D.B., George, M.L.C. and Cruz, Q.D.D. (2010). nalysis of Genetic Diversity within Nepalese Maize Populations Using SSR Markers. Nepal Journal of Science and Technology, 11: 1-8. 
Jompuk, P., Wongyai, W., Jampatong, C. and Apisitvanich, S. (2006). Detection of Quality Protein Maize (QPM) using Simple Sequence Repeat (SSR) Markers and Analysis of Tryptophan Content in Endosperm. Kasetsart Journal of Social Sciences, 40: 768 - 774.

Joshi, B.K., Acharya, A., Gauchan, D. and Bhatta, M. (2017). Agrobiodiversity status and conservation options and methods. In: Joshi, B. K., H. B. KC \& A. K. Acharya (eds.), Conservation and Utilization of Agricultural Plant Genetic Resources in Nepal. Proceedings of 2nd National Workshop, 22-23 May 2017, Dhulikhel. NAGRC, FDD, DoA and MoAD, Kathmandu, Nepal. Pp. 21-38.

Joshi, B.K. (2017). Plant breeding in Nepal: Past, present and future. Journal of Agriculture and Forestry University, 1:1-33.

Joshi, B.K., Gorkhali, N.A., Pradhan, N., Ghimire, K.H., Gotame, T.P., Kc, P., Mainali, R.P., Karkee, A. and Paneru, R.B. (2020). Agrobiodiversity and its Conservation in Nepal. Journal of Nepal Agricultural Research Council, 6: 14-33.

Krishna, M.S.R., Sokka Reddy, S., Rani, C., Reddy, T. and Jabeen, F. (2012). Molecular Genetic diversity analysis of Quality Protein Maize lines using SSR markers. The Andhra Agicultural Journal, 59: 533-537.

Kumari, A., Sinha, S., Rashmi, K., Mandal, S.S. and Sahay, S. (2018). Genetic diversity analysis in maize (Zea mays L.) using SSR markers. Journal of Pharmacognosy and Phytochemistry, 7: 1116-1120.

McDaniel, J. and S. D. Pillai. (2002). Gel alignment and band scoring for DNA fingerprinting using Adobe Photoshop. BioTechniques, 32:120-123.

Mohan, M., Nair, S., Bhagwat, A., Krishna, T.G., Yano, M., Bhatia, C.R. and Sasaki, T. (1997). Genome mapping, molecular markers and marker-assisted selection in crop plants. Molecular Breeding, 3: 87-103.

NAGRC, (2019). Annual report 2075/76 (2018/19). Khumaltar, Kathmandu, National Agriculture Genetic Resources Center, NARC.

Nguyen, T.V., Doan, T.T.B., Leo, A.E., Bui, C.M., Taylor, P.W.J. and Ford, R. (2012). Application of Microsatellite Markers to Fingerprint and Determine the Representational Diversity within a Recently Established Elite Maize Inbred Line Breeding Program. Journal of Agricultural Science, 4: 258-266.

Powell, W., Morgante, M., Andre, C., Hanafey, M., Vogel, J., Tingey, S. and Rafalski, A. (1996). The comparison of RFLP, RAPD, AFLP and SSR (microsatellite) markers for germplasm analysis. Molecular Breeding, 2: 225-238.

Prasanna, B., Pixley, K., Warburton, M. and Xie, C. (2010). Molecular marker-assisted breeding options for maize improvement in Asia. Molecular Breeding, 26: 339-356.

Ranatunga, M.A.B., Meenakshisundaram, P., Arumugachamy, S. and Maheswaran, M. (2009). Genetic diversity analysis of maize (Zea mays L.) inbreds determined with morphometric traits and simple sequence repeat markers. Maydica, 54: 113-123.

Reif, J.C., Melchinger, A.E., Xia, X.C., Warburton, M.L., Hoisington, D.A., Vasal, S.K., Srinivasan, G., Bohn, M. and Frisch, M. (2003). Genetic Distance Based on Simple Sequence Repeats and Heterosis in Tropical Maize Populations. Crop Science, 43: $1275-1282$. 
Senior, M.L., Murphy, J.P. Goodman, M.M. and Stuber, C.W. (1998). Utility of SSRs for determining genetic similarities and relationships in maize using an agarose gel system. Crop Science, 38: 1088-1099.

Shiri, M. (2011). Identification of informative simple sequence repeat (SSR) markers for drought tolerance in maize. African Journal of Biotechnology, 10: 16414-16420.

Singh, A., Sharma, J. and Lata, S. (2014). DNA fingerprinting of commercial maize hybrids and their parental lines using simple sequence repeat markers. Crop Improvement, 41:69-75.

Upadhyay, M.P. and Joshi, B.K. (2003). Nepal chapter. Plant Genetic Resources in SAARC countries: Their conservation and management. SAARC Agriculture Information Center, Dhaka, Bangladesh, Pp. 297-422. 